\title{
The University and the State in a Global Age: renegotiating the traditional social contract? ${ }^{[1]}$
}

\author{
MAREK KWIEK \\ Poznan University, Poland
}

\begin{abstract}
This article is based on the Keynote Address to the European Conference on Educational Research (ECER), Dublin, Ireland, 7-10 September 2005. It argues that we are facing the simultaneous renegotiation of the major post-war social contract (concerning the welfare state) in Europe and the renegotiation of a smaller-scale modern social pact: the pact between the university and the nationstate. It suggests that the current, and especially future, transformations of the university are not fully clear outside of the context of transformations to the state (and to the public sector) under global pressures. These pressures, both directly and indirectly, will not leave the university as an institution unaffected. Thus it is more useful today than ever before to discuss the future of the university in the context of the current transformations of the state. The study is divided into four sections: a brief introduction; a section on the university and the welfare state in Europe; a section on the university and the nation-state in Europe; and tentative conclusions.
\end{abstract}

\section{Part I. Introduction}

\section{Renegotiating Two Social Contracts}

It paper argues for a strong thesis according to which we are facing the simultaneous renegotiation of the post-war social contract concerning the welfare state in Europe and the accompanying renegotiation of a smaller-scale, by comparison, modern social pact between the university and the nation-state. The renegotiation of the latter is not clear outside of the context of the former, as state-funded higher education formed one of the bedrocks of the European welfare system.[2] It is the overall argument that current transformations to the state under the pressures of globalisation will not eventually leave the university unaffected, and consequently it is useful to discuss the university in the context of the current global transformations of the state. The institution of the university seems already to have found it legitimate and necessary to evolve together with radical transformations of its social setting. For in the new global order, against the odds, universities are striving to maintain their traditionally pivotal role in society. The role of universities as engines of economic growth, contributors to economic competitiveness and suppliers of well-trained workers for the new knowledge-driven economy is being widely acknowledged. But it is undoubtedly a radical reformulation of the traditional social roles of the university. The main reasons for these transformations of the university include the globalisation pressures on nation-states and its public services, the end of the 'Golden Age' of the Keynesian welfare state as we have known it, and the emergence of knowledge-based societies and knowledge-driven economies.

More generally, the processes affecting the university today are not any different from those affecting the outside world; under both external pressures (like globalisation) and internal pressures (like changing demographics, the ageing of societies, maturation of welfare states, post-patriarchal family patterns and so forth), the processes in question are the individualisation (and 
recommodification) of our societies and the denationalisation (and desocialisation) of our economies. On top of that, we are beginning to feel at universities the full effects of the universalisation of higher education and the increasing commodification of research.

\section{The Point of Departure: four assumptions}

Thus, in more detail, we are taking as a point of departure a number of loosely interrelated assumptions. First, higher education has been largely publicly-funded in its traditional European forms and its period of greatest growth coincided with the development of the post-war welfare state. Second, we are currently witnessing the growing significance of knowledge production, acquisition, dissemination and application in the emergent knowledge-based societies and economies on the one hand - and the still mostly traditional role of European higher education systems in the (shrinking, being restructured, retrenched and so on) public sector on the other. Third, we are witnessing the pressures of global forces on both national policies with respect to the welfare state and on national budgets accompanied by the ideas (and ideals) of the 'minimalist' - or, more recently, 'effective', 'intelligent' and so forth - state with smaller social duties than we were used to in the West under post-war welfare systems. Fourth, we are witnessing more general attempts at a reformulation of the post-war social contract which gave rise to the welfare state as we know it (with public higher education as we know it). Given all these assumptions, and many other accompanying factors, what is the future of our universities? What is going to happen to their uniqueness in society, culture, politics, and the economy? What is going to happen to the traditional idea (although in many different forms) of the university in the new world we are entering? One reservation has to be added at this point - the address has been strongly influenced by the geographical location of its author: the countries of central and eastern Europe with their higher education systems 'in transition'.

One of the central assumptions of the present address is that it is not satisfactory to discuss the institution of the university solely or mostly in the context of (national or comparative) higher education studies. The picture of the contemporary dynamics surrounding the institution and, especially, its future can no longer be discussed solely in traditional, relatively self-enclosed disciplinary contexts. Consequently, the university here is seen from a variety of perspectives and through the lenses of a wide range of disciplines (mainly educational sciences, political economy, sociology, political sciences and philosophy).

So we begin here from the fact that in Europe, within the Humboldtian tradition, the nationstate has for a period of almost 200 years forged links with the modern institution of the university as the provider of national consciousness and national culture, as well as the social and national glue for emergent European nation-states; and we commence also from the fact that the welfare state has contributed to an unprecedented growth in public higher education and the unprecedented educational attainments of individuals, social groups, and nations, especially in the post-war period.

\section{Public Good, Private Good and a Paradox of the University in the Knowledge Society}

As educational policies in a European welfare-state context used to view higher education as a mostly public (or social) good, and as this view justified an ever- increasing or at least good funding for national higher education and research and development systems - does the emergent redefinition of higher education as a private good (or individual good) favour a smaller funding engagement on the part of the state?[3] Or maybe the view of higher education as a private good is balanced by the increased need for higher education in knowledge-based societies, so that from the perspective of 'social capital' it allows universities to continue to rely solely or mostly on public funds for their functioning? There is a clear paradox here: higher education is seen as more important than ever before in terms of the competitiveness between nations, but though the importance of 'knowledge' in our societies is greater than ever, at the same time, along with the pressures to reform current welfare state systems, the capacity of national governments to finance higher education is considerably weaker than in previous decades, and may tend to be even smaller in the future. National governments have little room for manoeuvre in allocating parts of the 
budget to different sectors in the new global economy (especially, but not exclusively, in transition countries).

Given the emphasis on the importance of knowledge production and dissemination in the emergent 'knowledge societies', somehow paradoxically, and somehow unexpectedly, higher education has found itself - along with other welfare services, but after health care provisions and national pension systems - part of the reforms in public sectors worldwide. The tension between the general attitude of governments and populations (education perceived as perhaps the primary asset of the individual) on the one hand and on the other hand the inability or unwillingness of the very same governments to maintain current levels of funding for it, not to mention the raising of the level of public funding for higher education and research in public universities - this tension is as strong as never before.

\section{The Disappearing Uniqueness of the University?}

Consequently, what can be clearly seen is the convergence of educational policies across the world in which higher education is often no longer viewed as something special or unique but as a direct, increasingly measurable factor for developing new knowledge-based economies. Global economic constraints, felt the world over, clearly limit the policy choices of national governments (including policy choices in education) and considerably reduce their room for manoeuvre. What is increasingly evident on a global scale is 'the market perspective' when thinking about public services, in the aforementioned health care, pension and education sectors. In another context, the institution of the university is playing a significant role in the processes relating to the emergence of common European higher education and research spaces. What is clear, though, is that in neither of them is the university seen in the traditional way we know from the debates prior to the advent of globalisation, the speeding up of the process of European integration and the passage from industrial and service societies to post-industrial, global, knowledge and information societies (see Kwiek, 2000, Kwiek 2003c).

\section{Part II. The University and the Welfare State}

Let us pass on now to the second section of the address - on the relationships between the university and the welfare state. In our new global order, universities are striving for a new place as they are increasingly unable to maintain their traditional roles and tasks. As Zygmunt Bauman, an eminent Polish-English sociologist put it in his essay on 'Universities: Old, New, and Different', the once evident functions of the universities are far from obvious today:

The principles which in the past seemed to legitimize beyond doubt the centrality of the universities are no more universally accepted, if not dismissed as obsolete or even retrospectively condemned (Bauman, 1997, p. 49).

Both the official discourses on the common European space in higher education and in research as well as a large part of the accompanying academic debates on the subject increasingly acknowledge that the current role of universities should be that of engines of economic growth for the new knowledge-driven economy. Thus, without many discussions about principles (such as those accompanying the emergence of the Humboldtian model of the university at the beginning of the nineteenth century or such as the major twentieth-century debates about the 'idea' of the university), the university in its European context seems to be about to enter willy-nilly a new era of its development (see Kwiek, 2003a).

\section{The Logic Underpinning the Address}

To begin with, and to enter a wider socio-political context of this address, I would like to refer now briefly to Ulrich Beck's account of globalization where it means above all one thing: 'denationalization - that is, the erosion of the national state, but also its possible transformation into a transnational state' (Beck, 2000a, p. 14, author's emphasis). For our purposes here, this characterisation is crucial: 
If the traditional model of the national state is to have any chance of survival at all ... the globalization process will have to become the criterion of national politics in every domain (in economics, law, military affairs, and so on. (Beck, 2000a, p. 15, emphasis added)

I would add, following Beck's logic, that there is no reason to believe that globalisation processes will not be present in elaborating national politics in the area of higher education as well. It is this logic which requires globalization be taken into account when discussing social domains that seem connected with the modern institution of the university; the idea is found in another formulation from Beck's The Brave New World of Work:

But the central scientific and political problem of the second modernity is that societies must respond to such [globalization-related] changes at all levels at once. In the end, therefore, it is illusory to debate the future of work without also discussing the future of the nation-state, the welfare-state and so on. (Beck, 2000b, p. 18, emphasis added)

The present address has been underpinned by a similar logic. Consequently, in my view, it is equally illusory to debate the future of (public) higher education, especially (public) universities, without discussing the complex issue of current transformations of the welfare state, the nationstate and the public sector resulting (mostly but not exclusively) from current globalisation pressures. The public university is increasingly viewed as merely part of the public sector and its traditional claims to social (and consequently economic and political) uniqueness are increasingly falling on deaf ears. Reforms of the public sector are under way worldwide, and the university has probably no real choice but to participate in them. Current debates about the future of the university are more central to public policy and wider public discussions than ever before. It is hardly possible to see the transformations to the institution of the university without seeing the transformations to the social fabric in which it has been embedded. The modern university, the product of (Beck's first, national - as opposed to the second, post-national) modernity, is under the very same pressures as other modern institutions and social arrangements.

\section{Closed, National Economic Spaces and the Welfare State: a larger context}

Let us pass on now for a moment to a larger context provided by political sciences. Many political scientists stress the idea that the economic space of the nation-state and national territorial borders no longer coincide. Good examples here are such authors as Fritz Scharpf, director of the Max Planck Institute for the Studies of Societies in Köln or John G. Ruggie of Harvard University. Consequently, the post-war 'embedded liberalism compromise' - the social contract between the state, market, and labour - does not work any more as it was designed to work within closed national economies. Scharpf argues that in the history of capitalism, the decades following the Second World War were 'unusual in the degree to which the boundaries of the territorial state had become coextensive with the boundaries of markets for capital, services, goods and labor' (Scharpf, 2000 , p. 254). Investment opportunities existed mainly within national economies and firms were mainly challenged by domestic competitors. At the time, however, when major European welfare state regimes were being constructed, it was not fully realised how much the success of marketcorrecting policies depended on the capacity of the territorial nation-states to control their economic boundaries. Under the forces of globalization, though, this controlling capacity was lost. 'The 'golden years' of the capitalist welfare state came to an end' (Scharpf, 2000, p. 255). The social contract which had allowed the nation-states in advanced capitalist countries to be accompanied by a welfare state originated right after the Second World War. With the advent of globalisation, it is eroding, though, to a different extent in different countries. The compact between state and society in post-war territorially-bounded national democracies was intended to mediate the deleterious domestic effects of post-war economic liberalisation (and was based on Enlightenment beliefs in scientific solutions to social problems).

This post-war compromise assigned specific policy roles to national governments - which governments are increasingly unable, or unwilling, to perform today. One of the indirect effects of globalization is its impact on the ability of the state to 'live up to its side of the postwar domestic compact' (Ruggie, 1997, p. 2). The emergence of global capital markets posed entirely new policy problems. The existing systems of supervision and regulation, systems of taxation and accounting, 
were created for a 'nation-based world economic landscape' (Ruggie, 1997, p. 2). Economic policies are becoming increasingly denationalised and the state is increasingly unable, or unwilling, to keep its promises from the Golden Age of the welfare state.[4] And the welfare state has traditionally been one of the main pillars in the appeal of nation-state construction. As Ruggie describes the process,

The postwar international economic order rested on a grand domestic bargain: societies were asked to embrace the change and dislocation attending international liberalization, but the state promised to cushion those effects, by means of its newly acquired economic and social policy roles....Increasingly, this compromise is surpassed and enveloped externally by forces it cannot easily grasp, and it finds itself being hollowed out from the inside by political postures it was intended to replace. (Ruggie, 1997, p. 8, emphasis added; see also Ruggie, 1982)

As we can see again, the power of the nation-state, and the power of the loyalty of its citizens, has rested on a firm belief in (historically unprecedented) welfare rights. When the Keynesian welfare state was formed, the role of the state was to find a fair balance between the state and the market which had fundamentally transformed post-war social relations in all the countries involved in this social experiment.[5] The task of this post-war institutional reconstruction was to devise a framework which would safeguard and aid the quest for domestic stability without triggering the mutually destructive external consequences that had plagued the inter-war period. In the approach of many political scientists, exemplified here by Scharpf and Ruggie, the impact of globaliSation on the nation-state is through undermining the founding ideas behind the post-war welfare state: through liberalisation and the opening up of economies, nation-states begin to lose their legitimacy provided, in vast measure, by a social contract valid only in closed, national economies.

Now, does it matter for our universities? It matters, and it matters a lot.

\section{From the Golden Age of the Welfare State to the Politics of Austerity}

In the 'Golden Age' of the post-war Keynesian welfare state in Europe (1950-75, roughly speaking), higher education was very important - as testified by the constant growth of student enrolments, an increasing number of higher education institutions, rapidly rising scholarisation rates and the relatively lavish public research funding available to universities, both in natural sciences, social sciences and the humanities. This massification of higher education was in full swing in Europe, with universalisation as its aim. The stagnation which started in the second half of the 1970s in Europe was perhaps the first symptom that the welfare system in the form designed for one period (the post-war reconstruction of Europe) might be not be working in a different period.[6] The social conditions had changed considerably: the post-war social contract was related to an industrial economy in a period of considerable growth; the male bread-winner model of work was changing; closed, national economies with largely national competition for investment, goods, products and services were becoming internationalised; the marriage of the nation-state and the welfare-state was under pressure, and so forth. The social agenda of the 1980s and 1990s changed radically: after the policies of the golden age of expansion, European welfare states have been shaped by what Paul Pierson, a Harvard-based political scientist, termed 'politics of austerity' (Pierson, 2001).[7]

\section{The End of the Welfare State as We Know It/Public Higher Education as We Know It?}

Social scientists have divergent views about the causes of the current pressures on the welfare state; they agree on a single point, though; we are facing the end of the welfare state as we know it. An interesting question is: does it also mean the end of public higher education as we know it?

It is necessary to make one reservation at this point: it would be misleading to say that the issue of higher education is widely discussed in welfare state debates, for example, in political sciences. Surprisingly, it is extremely rare to see more than a few parenthetical remarks on education, not to mention higher education, in these debates. For obvious reasons, the major issue in these debates is the future of the welfare state in very general terms, with both theoretical research and more empirically-oriented studies devoted to health care systems and pensions systems (as the two biggest and fastest-growing consumers of welfare state resources) and 
unemployment issues. While there are quite a few articles and studies which closely link higher education and the nation-state, there are very few analysing the links forged between higher education and the welfare-state. The issue seems to be largely disregarded by higher education specialists, with notable exceptions, for example, in the United Kingdom (UK) (see for instance a recent UK ESRC-funded project on change agents in the public services: education and healthcare).[8] On reviewing the existing literature, it should be stated that while the interrelations between nationhood, the nation-state, higher education and globalisation are perceived as important for the future of the Humboldtian model of the research university, the parallel interrelations between the potentially collapsing post-war social contract between the Keynesian welfare state and higher education - are somehow, in general terms, underresearched.

\section{Why Does the University/Welfare State Connection Seem Underresearched?}

There may be several reasons for this: an American understanding of 'welfare' refers much more to social security, unemployment benefits [9], and social safety nets in general (and education seems to be excluded in most general accounts), and Anglo-Saxon discussions about the dismantling, retrenchment, and restructuring of the welfare state have for the most part been dominating the discussions since the mid-1990s; in a European context, on the other hand, even though the welfare state has been debated, such radical transformations of higher education as those observed in the Anglo-Saxon world (the UK, USA, Australia, New Zealand, and Canada) have not actually been perceived and analysed; additionally, the transnational and neo-liberal contexts of thinking about higher education were much less interesting to European scholars than to, for example, AngloSaxon scholars, often directly affected by new neo-liberal educational policies in their own institutions; however, in a European context, one of the major issues to have been discussed was 'European' welfare and the European social model, or the future of this model in integrating Europe. These issues - the 'minimalist state' promoted until recently by the World Bank and some development agencies in Latin America and in several European and post-Soviet transition countries, the 'downsizing' (or 'rightsizing') of the public sector in general, the changing balance between the state and the market in providing public services (including educational services), and the privatisation of education (together with, or following, the privatisation of the health care and pension systems) - are directly related to the future of the university, but have largely been absent from the debates about the welfare state in Europe.[10]

Consequently, the link between higher education as a significant part of the public sector (under scrutiny globally) and the welfare state has been largely overlooked for, so to speak, structural reasons: in Anglo-Saxon countries education traditionally does not belong in a general sense to the 'welfare state'; in Continental Europe, by contrast, there has so far been no actual major restructuring with respect to education as part of redefining the future role(s) of the welfare state.

Paradoxically enough it was in central and eastern Europe, exposed to the influences of global agencies in redefining their future models of the welfare state and consequently national welfare policies, that the direct link between the new 'effective' state on the one hand, with a downsizing of the public sector and a redefined minimal welfare state, and higher education policies on the other, was very much visible.[11]

Thus I want to argue that in the context of debates about the future of higher education, and of universities in particular, the close links between the welfare state and the nation-state have not been emphasized enough. Although the university/globalisation/nation-state nexus has been thoroughly studied, the parallel nexus of the university/globalisation/welfare state is largely underresearched, the links between the university and the welfare state being somehow underestimated. From my perspective, it is very promising to do research in this direction, and to keep seeing transformations of the university closer to transformations of the state. Let us also remember what such social scientists as Ramesh Mishra, Gary Teeple and Anthony Giddens emphasize - that the welfare state developed and still remains a 'national enterprise' (Mishra, 1999, p. 11); that the nation-state was the 'political and operational framework of the welfare state. That is, social reforms have been defined and administered as national programs' (Teeple, 1995, p. 18). Or, as Anthony Giddens argued in Beyond Left and Right: the future of radical politics, 
The welfare state has always been a national state and this connection is far from coincidental ... Who says welfare state says nation-state. (Giddens, 1994, p. 136, emphasis added)

The National Economy: a common economic boat for all, not any more?

The welfare state was an integrated national state in which there was no big difference between wealth and national wealth - which in many places may no longer be the case. This was presented in the most dramatic way by Robert B. Reich in The Work of Nations through the transition from a metaphor of the citizens being in the same large boat (called 'the national economy') to a metaphor of the citizens increasingly occupying different, smaller, individual boats. In Reich's view, Americans (or citizens of any other nation for that matter) are no longer in the same economic boat, there is no longer any common economic fate for citizens of a given nation. The centrifugal forces of the global economy tear at the ties binding citizens of national states together (see Reich, 1992).

No matter how we view the origins of current reformulations of the welfare state (more radical in theory than in actual practice in most countries but already perceived in changing national policies, national legislation and the general attitude taken towards the public sector), and no matter whether we link them to the impact of domestic and internal developments or to external and global forces, they cannot be denied. As Giuliano Bonoli et al phrased it in European Welfare Futures: towards a theory of retrenchment,

There are no voices that globalization has increased government power....There is general agreement that the forces of globalization have important implications for the volume, the generosity and the composition of contemporary European welfare state provision. (Bonoli et al, 2000, p. 65)

Using a strong façon de parler, the end of the world as we know it - not quite atypical sociological description of a global age - means also the end of the social and economic world as we know it. And it is the impact of these transformations on the institution of the university, or on publiclyfunded higher education in more general terms, that is under discussion in this section.

\section{Broad Outline and Crucial Social Phenomena Revisited}

In broad outline, the current situation may be described as the simultaneous renegotiation of the post-war social contract concerning the welfare state and the renegotiation of a smaller-scale, by comparison, modern social pact between the university and the nation-state (or between knowledge and power).[12] The renegotiation of the pact between the university and the state is not clear outside of the context of the renegotiation of the post-war welfare state contract, as statefunded higher education formed one of the bedrocks of the European welfare system.[13]

The social phenomena of greatest interest to me in this keynote are the recommodification of society, the desocialisation of the economy, the denationalisation of both societies and economies, the deterritorialisation and despatialisation of economic activities, the changing distribution of risks in society, the growing individualisation, the growing market orientation in thinking about the state and public services, the disempowerment of the nation-state, the globalisation and transnationalisation of welfare spending patterns, and the detraditionalisation of nationhood and citizenship. They all influence the way welfare issues are perceived. By analogy, most of them may influence the way higher education is perceived. And these processes are at least intensified by globalisation. What we can see as the current situation of the welfare state, and how we can see the issue, is largely framed by the processes, phenomena and interpretations that globalisation has already brought about.

\section{Part III. The Modern University and the Modern Nation-State}

So far we have been dealing with the relationships between the university and welfare state; let us pass on to the second crucial dimension of the problem of state/university relationships and the third section of the present address - the nation-state (and let us leave our regional 'European 
Union' dimension of the problem for another occasion, especially that we have dealt with it in more detail elsewhere, see Kwiek, 2004b, 2005).

\section{National Identities, National Community and the University}

It is the overall argument of the present keynote address that current transformations to the state under the pressures of globalization will not eventually leave the university unaffected, and consequently it is useful to discuss the future tasks and mission of the university in the context of the current global transformations of the state. To disregard this context would be a an analytical mistake. Just to signal further developments: the legitimacy of, and loyalty towards, modern liberal democratic welfare states is under severe stress today and the whole idea of a (European) post-war 'social contract' between the state and its citizens is widely debated. The sovereignty of the state meant also the sovereignty of national educational policies and full state support for nation-state oriented universities (from their inception as modern institutions bound by a 'pact' with modern nation-states). The university used to provide the modern nation-state with 'a moral and spiritual basis' and professors, as Gerard Delanty argues in Challenging Knowledge: the university in the knowledge society along Humboldtian lines, 'constructed themselves as the representatives of the nation' (Delanty, 2001, pp. 33, 34).

National education systems were created as part of the state forming process which established the modern nation-state. They were born when states based on absolutistic or monarchical rule gave way to the modern nation-state: as Andy Green stresses in his Education, Globalization and the Nation-State, the history of 'national education' is thus very much the history of the 'nation state in formation' (Green, 1997, p. 131). National education systems contributed to the creation of civic loyalties and national identities and became guardians for national languages, cultures, literatures and consciousness. The modern university and the modern nation-state went hand in hand, or were parts of the same wide process of modernisation. Consequently, as we claim here, reconfigurations of the modern nation-state today (mostly, but not exclusively, under the pressures of globalisation) are bound to affect the modern institution of the university. Statesponsored mass education is, in modernity, the primary source of socialisation facing the individual as citizen of a nation-state (see Spybey, 1996). European nation-states were engaged in authorising, funding and managing education systems, including higher education, to construct unified national polities.

\section{Nationalisation of the University - becoming a public responsibility}

We do need a bit of a historical excursus here. The crucial step in the historical development of European universities for our purposes here is what Guy Neave termed the process of their nationalisation - bringing the university formally into the public domain as a national responsibility. With the rise of the nation-state, the university was set at the apex of institutions defining national identity (Neave, 2001, p. 26, see also Neave 2000a). The emergence of the universities in Berlin and in Paris marked the termination of the long process for the incorporation of the university to the state (Neave, 2001, p. 25).

The process of the 'nationalisation' of the university settled the issue of what the role and responsibilities of the modern institution in society should be. The emergent nation-state defined the social place of the emergent modern university and determined its social responsibilities. The nation-state determined the community to which the university would be answerable: it was going to be the national community, the nation. The services and benefits the unitary and homogeneous nation-state gradually, and over the passage of time, placed at the disposal of society went far beyond education and included, for example, generous health care systems and old-age pension schemes.

Nowadays, as the reduction of the welfare state in general progresses smoothly (and mostly in an unnoticeable manner, for example, through new legislation) in most parts of the world, social contracts with regards to these (and possibly other) areas of state benefits and state-funded services may have to be renegotiated, significantly changing their content. In many respects, higher education (in transition countries and elsewhere) seems to be an experimental area and a testing 
ground on how to reform the public sector in many countries and for many organisations; both healthcare and pensions systems are being experimented with as well but on a smaller scale, both in theory and in practice.[14]

\section{Cultural vs. Political Unity of the Nation: the role of the modern university}

We come to a point in which we have to depart slightly from Guy Neave's reading of the relationship between the Humboldtian university and the nation-state. While Neave in his essays stresses that aspect of the Humboldtian - and German Idealists' generally - interpretation of the university in which 'culture, science and learning existed over and above the state' and in which 'the responsibility of the university was to act as the highest expression of cultural unity' (Neave, 2001, p. 25, emphases added), I would like to stress the national aspect of Bildung and the role of the university as conceived by the German thinkers in the production of national consciousness, providing the national glue to keep citizens together, fostering national loyalty and supporting not only the nationhood in cultural terms but also the nation-state in political terms.

Consequently, I would like to weaken the sharp opposition presented by Neave between the Napoleonic model of the university and the political unity of the nation on the one hand, and the German model of the university and the cultural unity of the nation on the other hand.[15] The opposition is clearly there, but the political aspect of the Humboldtian reforms to the German university, fully complementary to the ideal of the 'pursuit of truth', should be emphasized as well. The political motif was present in German thinking about the idea of the university from Kant to Humboldt and reached perhaps its full-blown shape in Martin Heidegger's Rectorial Address pronounced at Freiburg in 1933 and in his attempts to use the modern university and his philosophy-inspired reforms of it directly for the political purposes of the new Germany.

Following detailed readings not only of Wilhelm von Humboldt but also Friedrich Schleiermacher, Johann Gottlieb Fichte and Friedrich W.J. Schelling (see Kwiek, 2005), we are inclined to stress the combination of cultural and political motifs in their formulations of the idea of the university rather than (following Neave) merely cultural ones; perhaps even the political cum cultural motif. The classical German notion of Bildung from that period, and from the writings of these philosophers, to a varying degree depending on the exact historical moment and a given author, is certainly very strongly politicised. It refers to the cultivation of the self and of the individual but also to the cultivation of the individual as a nation-state citizen. I am in agreement here with the late Bill Readings who emphasizes in his The University in Ruins that German Idealists

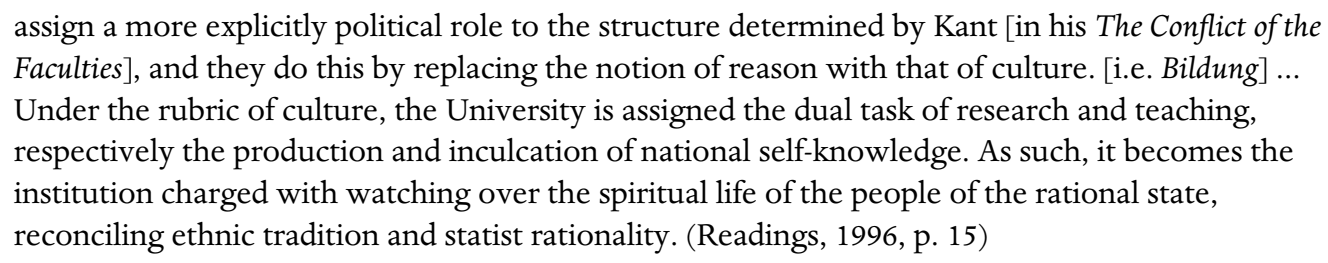

Consequently, with Readings and against Neave, we do not see the distinction between what was the political unity of the nation and what was the cultural unity of the nation (in their relationship to the institution of the university) as sharply as Neave does and we want to soften this distinction considerably. In our view, the national (and political) component in the German idea of the university, and the role assigned to the German nation in the writings of German philosophers accompanying the emergence of the University of Berlin, were considerable.

The tension between 'the pursuit of truth' and 'public responsibility' in the evolution of the modern university, Neave stresses, has been very clear in German writings on academia. The dichotomy is clearly present in the founding fathers of the German university as well. There is a clear tension between thinking about science and the community of scholars and students, truth and universality on the one hand, and the national consciousness, nationhood, the state and academic responsibilities to them on the other. The immediate reason to rethink the institution of the university, was political: the defeat by the French on the battlefield. It was clearly Fichte who was the most nation-oriented in his ideas of the university, and it is no accident that it was Fichte's thinking that influenced Heidegger's ideas on the university most, slightly more than 100 years later. 
Forging National Identity and Pursuing Truth - both motifs dead and gone today?

Increasingly, at the beginning of the nineteenth century, culture in the sense of Bildung became mixed with political motivations and aspirations, focused around the notion of the German national state. It is interesting to note that in a global age, both motifs have been put under enormous pressure. Forging national identity, serving as a repository of the nation's historical, scientific or literary achievements, inculcating national consciousness and loyalty to fellow-citizens of the nation-state do not serve as the rationale for the existence of the institution of the university any more; but also the production of a 'disciplined and reliable workforce' is not fulfilling the demands of the new global economy which requires workers with the capacity to learn quickly and to work in teams in reliable and creative ways - Robert B. Reich's 'symbolic analysts' - as Raymond A. Morrow and Carlos Alberto Torres emphasize (Morrow \& Torres, 2000, p. 33). At the same time, the disinterested pursuit of truth by curiosity-driven scholars in the traditional sense of the term is no longer accepted as a raison d'être for the institution either (see Kwiek, 2004a, and 2004b on the Bologna Process). Consequently, no matter whether we focus more on the cultural unity of the nation or on the political unity of the nation as the two distinct driving forces behind the development of the modern university, both motifs are dead and gone in post-national and global conditions. Neither serving truth, nor serving the nation (and the nation-state) can be the guiding principles for the functioning of the institution today, and neither of them are even mentioned in current debates on a global or European level (it is sufficient to read the communications of the European Commission about the role of the university and research and development activities in knowledge-based societies or World Bank's and the Organisation for Economic Development (OECD)'s views on the future role of the university which are underpinning reforms of higher education in most transition and developing countries today; see OECD 1998; World Bank, 2002; European Commission, 2003).

The move towards the 'nationalisation' of the university was strong and the process of linking the university to the national state continued throughout the nineteenth century (as one commentator remarked, 'the universalization of the nation-state went hand in hand with the 'nationalization' of culture'; see Axtmann, 2004, p. 260). The social purpose, missions and roles of the university in the emergent national state were redefined anew. Emergent higher education systems were clearly national systems, with their own national priorities and distinctive patterns of validation and certification of knowledge and education. Civil service in the nation-state was closely linked with national universities and at the same time scholars (especially full professors) in some countries - gained the status of public servants. The 'nationalisation' of higher education was inseparable from the 'nationalisation' of scholars: the introduction of the civil service status for senior academics served also 'to impress firmly upon the consciousness of academia its role as an emanation of the national wisdom and genius, creativity and interest' (Neave, 2001, p. 30).

\section{The Role of the University: from political integration to a 'production process'?}

To have a fully updated picture now: the process of the 'nationalisation' of the university so vividly described by Neave has come to a close right now, together with the advent of globalisation. I am in full agreement with the three implications of globalisation for the institution of the university which Neave draws. First, globalisation brings to a close the process of the incorporation of the university into the service of the state; second, globalisation redefines the place of the university in society - from 'an instrument for political integration' to 'part of the "productive process"', a driver of economic integration between nations; and third, it is the corporation that becomes 'the basic organizational paradigm for the university' (Neave, 2000b, pp. 16-17) or 'society's central referential institution', as he puts it elsewhere (Neave, 2001, p. 48).

To rephrase it - the processes of globalisation disentangle the university from the state, turn the university potentially into a major contributor to global economic competition and increasingly impose on it corporate models of organisation. Consequently, the social mission of the university is under scrutiny and, as Neave says, such processes as privatisation, deregulation and accountability in higher education appear to be moving the university 'without the slightest shadow of a doubt towards a new definition of its responsibilities' (Neave, 2000b, p. 23). The possible new future contract between society and the university will certainly include points directly related to the 
academic profession - whose current social status, working and employment conditions are already under scrutiny (for Poland, see Kwiek, 2003b). The direction of these changes can already be imagined from numerous studies of the academic profession from a global perspective; hopefully, they can still be renegotiated (see, for example, the two major international projects on the academic profession in which the author has participated: Altbach, 2002 and Enders \& de Weert, 2004).

\section{Delinking of the University from the State - a tribute to Bill Readings}

The first scholar to have focused attention on the close link between the modern university, the state and global economic transformations was the late Bill Readings in his The University in Ruins (1996). He almost never used the word 'globalisation' but referred to a more culturally-loaded notion of 'Americanisation'; he also never used the words 'welfare state' or 'knowledge society', nor ever developed the theme of the modern university as part of the public sector and an important segment of modern welfare regimes. His vision of the university and of globalisation/Americanisation, as many commentators noted, was overstated, oversimplified and exaggerated; but at the same time, even in exaggerated forms, it may have hit the mark when discussing the university's possible future trajectories (see Kwiek, 2000). As a philosopher and student of culture, he was somewhat aware of global transformations in finance and production, of the liberalisation of trade and the opening of national economies, of the convergence of global thinking about the state and its future roles - but never articulated these ideas more than in passing. His thesis of the emergence of the post-historical 'university of excellence' that is replacing the traditional modern German 'university of culture' is strong but overstated in a postmodern manner. As Gerard Delanty suggests, Readings' postmodern position has little to offer - presents no alternative scenario (Delanty, 2001, pp. 6, 140). Many others became involved in studies on the corporatisation, marketisation and commodification of the university; studies of managerialism in the public sector, including higher education, as well as in studies of the academic profession, all mostly unknown to a wider audience in the mid-1990s when Readings was completing his book. There is one point which I want to focus on from his book, though. It is his stubborn linking of the modern university to the emergent German nation-state, and the current delinking of the institution from the state. Readings argues that

$[\mathrm{T}]$ he University is becoming a different kind of institution, one that is no longer linked to the destiny of the nation-state by virtue of its role as producer, protector, and inculcator of an idea of national culture. (Readings, 1996, p. 3)

Without going into the details of the evidence provided by political economists, political scientists, and students of globalisation and of the welfare state, Readings makes his point: the modern university has outlived itself, it is no longer functioning as an 'ideological arm' of the nation-state (Readings, 1996, p. 11). He views culture as a symbolic and political counterpart to the project of the nation-state:

The nation-state and the modern notion of culture arose together, and they are ceasing to be essential to an increasingly transnational economy. This shift has major implications for the University, which has historically been the primary institution of national culture in the modern nation-state. (Readings, 1996, p. 12)

The role of the nation-state through the global circulation of capital is changing, and so is the role of the university. It does not have to - although it may want to - safeguard and propagate national culture, does not have to train citizen subjects of the nation-state, does not have to watch over the spiritual life of the people, produce and inculcate national self-knowledge, and provide a social glue necessary to keep the citizens of the nation-state together. Its traditional cultural and political mission closely related to the political project of the nation-state is clearly over. The decline of the nation-state changes the mission of the university.

What Readings suggested somehow intuitively about the transformations of citizenship and national consciousness (as a necessary social glue) under globalisation pressures, gains new significance today. He never mentioned neo-liberal attempts to reform the public sector, or 'rightsizing' of the state, or retrenchment of the welfare state, and never discussed policies for the 
restructuring of higher education institutions and the global convergence of education and research and development policies along the lines suggested by the emergent notion of the 'knowledge society' (and 'knowledge economy'). But in terms of painting a larger picture of ongoing transformations of the institution of the university, and through reformulating his ideas into new discourses and new areas of intellectual inquiry, we can still learn a lot from him - although in a different (pre-globalisation, so to speak) vocabulary.

\section{Higher Education vs. Civil, Political and Social Citizenship}

There is also an increasing awareness of the artificiality, or at least of the constructed nature, of nation-state citizenship. As Mike Bottery of the University of Hull argues, it is only at the present time that 'the political body defining the terms and boundaries of citizenship is something called "the nation-state"' (Bottery, 2003, p. 102). Bottery stresses that nation-state citizenship involves a form of exchange, even if such an exchange is rarely fully articulated. In return for a transfer of identification and loyalty from the local and regional level to that of the nation-state, nation-states have provided its citizens with civil citizenship (the right to freedom of speech, rights to justice and the ownership of property), political citizenship (the right to be involved in the exercise of political power) and social citizenship (the right to health care and economic security and educational provision) (Bottery, 2003, p. 103ff.). What is of major interest to us here is the social citizenship. The loyalty of citizens of nation-states is closely related to this 'bilateral' agreement, although never fully codified, between citizens and the state. Should the nation-state be threatened, so also will its role as primary guarantor of citizenship rights.

Globalisation seems to be changing the role of the nation-state: the nation state is gradually losing its power as a direct economic player and at the same time it is losing a significant part of its legitimacy as it appears not to be willing, or able, to provide the welfare services seen as the very foundation of the post-war welfare state. Nation-states seem to prefer not to use the financial space of manoeuvre still left to them, even if they could be much more proactive than reactive with respect to the impact of globalization on public services, including higher education.

\section{Public Sector Reforms and Finance-driven Reforms}

Western liberal democracies are reforming, or trying to reform, their welfare state institutions, and the modern university, as a claimant on public resources, is a significant part of the welfare sector. The costs of both teaching and research are escalating, as are the costs of maintaining advanced health care systems and other segments of the welfare state, and consequently the whole public sector is under new, mostly unheard of before, and mostly financial, pressures. In this context one way that globalisation has had a major impact on education has been through what Stanford-based Martin Carnoy termed 'finance-driven reforms' (as opposed to 'competitiveness-driven reforms' and 'equity-driven reforms'; see Carnoy, 1999: p. 42ff.) the main goal of which is to reduce public spending on education. As he argues in Globalization and Educational Reform: what planners need to know, the former set of reforms may contribute to the shortage of public resources for education 'even when more resources could be made available to education with net gains for economic growth' (Carnoy, 1999, p. 52).

It is important to remember that linking economic and social change to changes in how societies transmit knowledge, as Martin Carnoy and Diana Rhoten argue, is a relatively new approach to studying education (Carnoy \& Rhoten, 2002, p. 1). Before the 1950s, comparative education focused mainly on the philosophical and cultural origins of educational systems: educational change was seen as resulting from changing educational philosophies. In the 1960s and 1970s this view was challenged by various historical studies in which educational reform was situated in economic and social contexts. Today, they claim, it is the phenomenon of globalisation that is providing a new empirical challenge and a new theoretical framework for rethinking higher education:

One point is fairly clear. If knowledge is fundamental to globalization, globalization should also have a profound impact on the transmission of knowledge. (Carnoy $\&$ Rhoten, 2002, p. 2) 
And the impact of globalization on the transmission of knowledge is the impact on, inter alia, education and educational institutions, especially at the higher level.[16] Carnoy argues elsewhere (Carnoy, 1999, p. 14) that although education appears to have changed little at the classroom level, globalisation is having a 'profound effect' on education at other levels. But at the heart of the relationship between globalisation and education is the 'relationship between the globalized political economy and the nation-state’ (Carnoy \& Rhoten, 2002, p. 3).[17]

\section{Changing Usefulness of the University: on economic vs. social and global vs. domestic concerns}

This major shift of concern by today's states is towards economic and global concerns at the expense of social and domestic ones, which makes the state completely different from what Bob Jessop called once 'The Keynesian National Welfare State' (Jessop, 1999, p. 348). What it may mean in practice is a shift in public spending and monetary policy: from measures favouring workers and consumers to those favouring financial interests. Or as Carnoy and Rhoten put it, 'globalization forces nationstates to focus more on acting as economic growth promoters for their national economies than as protectors of the national identity or a nationalist project' (Carnoy $\&$ Rhoten, 2002, p. 3)

Consequently, the role of universities seems quite different from these two perspectives: the traditional (modern, national) perspective saw universities as useful instruments for inculcating national identity and the new (post-national, global) one sees universities as (equally useful) instruments in promoting economic growth and boosting national economies. At the same time, the debate on the university today comes as part and parcel of a much wider debate on the public sector (and state intervention in, or provision of, different, traditionally public, services).

\section{Part IV. Tentative Conclusions}

Thus, finally, there are four tentative conclusions. First of all, higher education institutions' traditional relations with the state are changing and the main forces of change in these relations are globalisation-related. This change is happening on a global scale, the patterns of transformations are very similar indeed, even though national and regional differences do exist. Higher education is likely to be strongly affected by these globalisation-related processes soon, or has already been affected by them - mainly through the indirect impact of the ongoing transformations to the state. Thus the effects of globalisation on the university are to a large extent indirect, via the transformations of the state.[18]

Secondly, higher education worldwide is much less a unique part of the public sector than it used to be a few decades ago: either in public perceptions, or in practical terms (financing and governance). This will heavily influence its future relations with the state which, on a global scale, is increasingly involved in reforming its public sector.

Thirdly, the transformation of higher education - both in terms of teaching and research seems inevitable, as the forces behind these changes are global in nature.[19] The forces of change are similar, although their current influence varies from country to country, and from region to region. Mass higher education may no longer be a dominant goal of states and governments as it has already been achieved as a goal in many of them: there are many other, competing, social needs today though. And even in the context of 'knowledge-based economies', the knowledge in question may not exactly be knowledge as currently produced and disseminated by traditional public universities, as is testified to in a European setting by the documents about the future of the institution prepared for discussion by the European Commission over the last five years or so.

Fourth and lastly, it is certainly not enough to understand today that reformed institutions for emergent knowledge societies are definitely needed, in different countries to different degrees; the point is to see why our institutions need to be changed, and why we need to take into account the issues of the state, the public services it provides, and the market setting in which they are bound to operate. It is increasingly difficult to understand the dynamics of possible future transformations in higher education today without understanding the transformations of the social world today, including transformations to the state and citizenship. And as one of the most striking features of the new world order is its increasingly global nature, neither policy makers nor policy-scholars in 
higher education can ignore the far-reaching (and still undefined!) impact of the ongoing transformations of the state on our traditional educational business.

\section{Notes}

[1] Annual European Educational Research Association (EERA) Congress - Keynote Address, Dublin, 9 September 2005.

[2] I sometimes use the terms 'university' and (public) 'higher education' interchangeably: in more historical contexts, especially in relationships with the nation-state, it is more often the former; as the educational landscape today is becoming increasingly diversified, in more general and more current contexts, it is 'higher education'. Wherever I want to mean, in Europe, the top national public institutions offering the traditional scope of areas of teaching and research, I tend to use the former too.

[3] Per Nyborg in his article 'Higher Education as a Public Good and a Public Responsibility' has drawn an interesting distinction between the notion of public good and that of public responsibility with respect to higher education. He argues that it may be more relevant to explore the implications of the public responsibility for higher education than to focus solely on the concept of the public good (see Nyborg, 2003, pp. 355-356).

[4] It is extremely hard to keep promises from the Golden Age of the welfare state while 'fiscal termites' are gnawing at the foundations of the fiscal house in all major developed economies. Vito Tanzi argues in 'Taxation and the Future of Social Protection' that the most direct and powerful impact of globalisation on the welfare state will probably come through its effect on tax systems: 'for the time being there is little, if any, evidence that the tax systems of the industrial countries are collapsing ... While the fiscal house is still standing and looks solid, one can visualize many fiscal termites that are busily gnawing at its foundations' (Tanzi, 2001, p. 192). Interestingly enough, the issue of high taxes is certainly not only globalisation-related but also hinges on the will of the electorate. As Martin Wolf argues, 'sustaining a high measure of redistributive taxation remains perfectly possible. The constraint is not globalisation, but the willingness of the electorate to tolerate high taxation' (Wolf, 2001, p. 188).

[5] Now we are experiencing what Ulrich Beck called (in World Risk Society) a 'domino effect': 'Things which used to supplement and reinforce one another in good times - full employment, pension savings, high tax revenue, leeway for government action - now tend mutatis mutandis to endanger one another' (Beck, 1999, p. 11).

[6] As Gøsta Esping-Andersen, one of the most eminent welfare scholars in Europe, put it recently in 'A Welfare State for the 21st Century', 'most European social protection systems were constructed in an era with a very different distribution and intensity of risks and needs than exist today ... As a consequence, the welfare state is burdened with responsibilities for which it was not designed' (EspingAndersen, 2001, p. 138, emphasis added).

[7] Consequently, the rhetoric of a 'crisis' in the welfare state has been with us since the 1970s. There was also a growing interest in non-state welfare providers. The OECD report, The Welfare State in Crisis, had already stated in 1981 that 'new relationships between action by the state and private action must be thought; new agents for welfare and well-being developed; the responsibilities of individuals for themselves and others reinforced' (OECD, 1981, p. 12).

[8] The project is directed by Mike Wallace and co-directed by Rosemary Deem, Mike Reed and Jon Morris. See also Rosemary Deem and Kevin J. Brehony, 'Management as Ideology: the case of 'new managerialism' in higher education' (2005). The present author uses a wider term of 'welfare state' where Wallace and colleagues speak in more detail, and on UK grounds, on 'public services'.

[9] See, for instance, an excellent book written at the beginning of the 1990s by Paul Pierson, entitled Dismantling the Welfare State?: Reagan, Thatcher, and the politics of retrenchment (Pierson, 1994). Pierson discusses programmatic retrenchment in three sectors: a core sector (old-age pensions), a vulnerable sector (housing policy) and a residual sector (income-support policy). Neither education in general, nor higher education in particular, are discussed in any detail, even though the period analysed would have provided universities with an excellent research topic. In his 'Coping With Permanent Austerity' essay, Pierson provides the following definition of the welfare state: “The welfare state” is generally taken to cover those aspects of government policy designed to protect against particular risks shared by broad segments of society. Standard features, not necessarily present in all countries, 
would include: protection against loss of earnings due to unemployment, sickness, disability, or old age; guaranteed access to health care; support for households with many children or an absent parent; and a variety of social services - child care, care of the eldery, and so forth - meant to assist households in balancing multiple activities which may overtax their own resources' (Pierson, 2001, p. 420). In contrast, European definitions most often include education.

[10] As Gary Teeple in his book Globalization and the Decline of the Social Reform reminds us, the privatisation of the welfare state can take different routes: 'The least visible and yet a widely taken route of privatization is the policy of incremental degradation of benefits and services' (Teeple, 1995, pp. 104-105). In the context of the last route, it is worth mentioning that this can be seen in the case of public higher education in many transition countries by looking at the national statistics concerning public investment in higher education and research and development over the last decade.

[11] One of the major differences between affluent western democracies and the European transition countries is that the point of departure for welfare transformations is different. Paul Pierson rightly notes that in most of the affluent democracies, the politics of social policy centers on the renegotiation and restructuring of the terms of the post-war social contract rather than its dismantling' (Pierson, 2001, p. 14). In the countries of central and eastern Europe, in general terms, there is no social contract to renegotiate and welfare provisions need to be defined from the very beginning. Consequently, while the dismantling of the welfare state, especially with strong democratic electoral structures and powerful civil society groups, might not occur in the near future in western Europe, the process might be long-term so that eased by social protection measures, an already 'dismantled' welfare state may be built along neo-liberal lines in CEE countries without actually renegotiating the post-war European social contract - which was absent there. Ideologically, there is an important difference between the potential dismantling of the welfare state (in western Europe) and the actual dismantling of the remnants of bureaucratic welfare from the ancient regime (in central and eastern Europe). It is extremely interesting to draw parallels between Paul Pierson's description of welfare state retrenchment in the United Kingdom and the United States (USA) (in the times of Reagan and Thatcher) and the ongoing welfare reforms in selected countries of central and eastern Europe (Poland being a natural and well-researched candidate).

[12] There is an accompanying - crucial, although somehow neglected - internal (academic) dimension to the issue as well. There has been a clear interdependence between decreasing state subsidies for universities, and academics becoming 'entrepreneurs' or 'academic capitalists', as shown by Sheila Slaughter and Larry L. Leslie regarding Canada, Australia, the USA and the UK. The uniqueness of the institution of the university seems to be less compelling since the above two processes became more widespread (which started in the 1980s). Certainly, the causal arrow goes from diminished state funding to increased academic entrepreneurialism, not the other way round. Slaughter and Leslie stress the significance of the participation of academia in the market which 'began to undercut the tacit contract between professors and society because the market put as much emphasis on the bottom line as on client welfare. The raison d'être for special treatment for universities, the training ground of professionals, as well as for professional privilege, was undermined, increasing the likelihood that universities, in the future, will be treated more like other organizations and professionals more like other workers' (Slaughter \& Leslie, 1997, p. 5).

[13] The three leading European social scientists - Jürgen Habermas, Ulrich Beck and Zygmunt Bauman view the social future of Europe from a wider perspective and provide additional arguments, through their rethinking of the welfare state, for the present author's point that the transformation of public higher education on a global scale is unavoidable. Habermas, Beck and Bauman, despite coming from different philosophical and sociological traditions, agree on one point: the transformations of the welfare state we are currently witnessing are irreversible, we are passing into a new age with respect to the balance between the economic and the social. With respect to welfare futures, the emergence of Habermas's (2001) 'postnational constellation' carries the same message as the emergence of Beck's 'second, postnational modernity' and Bauman's 'liquid modernity': the traditional post-war Keynesian welfare state, with its powerful 'nation-state' component, is doomed, and for the three thinkers the culprit behind the end of this social project in Europe is globalisation, in its theories and its practices. None of them focuses on the internal developments of the European welfare state (like changing demographics, including the ageing of western societies; shifts in familial structures; the burden of past entitlements within the inter-generational contract between the old 
and the young, the working and the unemployed and so on); they clearly link the new geography of social risks and uncertainties with the advent of - mainly economic - globalisation.

[14] The biggest empirical evidence for the direction of changes in the transformation of the public sector are various 'structural adjustment' programmes in developing and transition countries which require the states taking International Monetary Fund (IMF) or World Bank loans to, for example, reduce public expenditures, reduce consumer subsidies, eliminate price controls, drastically reduce tariffs, charge users for public services and privatise public enterprises and social services (see Carnoy, 1999, p. 49, Ferge, 2001). With respect to education, structural adjustment policies are linked to globalisation to the extent that 'all strategies of development are now linked to the imperatives of creating stability for foreign capital' (Morrow \& Torres, 2000, p. 43, see also Torres, 2002). Recipient governments are encouraged to adopt policies which Thomas L. Friedman termed (in Lexus and the Olive Tree) 'the Golden Straightjacket'.

[15] There are three main principles of the modern university to be found in German thinkers, the founding fathers of the University of Berlin. The first principle is the unity of research and teaching (die Einheit von Forschung und Lehre); the second is the protection of academic freedom: the freedom to teach (Lehrfreiheit) and the freedom to learn (Lernfreiheit); and the third is the central importance of the faculty of philosophy (the faculty of Arts and Sciences in modern terminology) (see Fallon, 1980, p. 28ff.; Röhrs, 1995, p. 24ff.). The three principles are developed, to varying degrees, in Schelling, Fichte, Schleiermacher and Humboldt. Together, the three principles have guided the modern institution of the university through the nineteenth century to the twentieth century, and possibly beyond. To what extent these principles are being questioned today, by whom and in what segments of the diversified systems of higher education is a different issue.

[16] For the project of the European integration, the theme of the new 'Europe of Knowledge' seems crucial; the emergent European educational and research space becomes a significant component of the 'revitalization' of the Europeanisation project. The foundations of the European knowledge society (and knowledge economy) are constructed around such pivotal notions as 'knowledge', 'innovation', 'research', 'education' and 'training'. Education, and especially 'lifelong learning', becomes a new discursive space in which European dreams of common citizenship are currently being located. A new 'knowledge-based Europe' is becoming individualised (individual learners rather than citizens of nation-states) and the construction of a new educational space can contribute to forging a new sense of European identity. It is possible that the idea of Europe and its founding myths and symbols are being redefined (see Lawn, 2003; Kwiek, 2004b).

[17] I am in full agreement with Anthony R. Welch when he argues that 'it is becoming increasingly difficult to understand education without reference to such [i.e. globalisation] processes' (Welch, 2001, p. 478).

[18] Here I am following Roger Dale in 'Specifying Globalization Effects on National Policy: a focus on the mechanisms', who argues that while states have retained their formal territorial sovereignty more or less intact, they have all, to a greater or lesser degree, lost some of their capacity 'to make national policy independently ... Absolutely central to arguments about the effect of globalization on public services like education is that those effects are largely indirect; that is to say, they are mediated through the effect of globalization on the discretion and direction of nation states' (Dale, 1999, p. 2, emphasis added).

[19] Hence the appearance of the Bologna process in higher education and of the Copenhagen-Brugges process in vocational education in Europe, as well as the need for the construction of a European Research Area along the lines suggested by the Lisbon strategy.

\section{References}

Altbach, P.G. (Ed.) (2002) The Decline of the Guru: the academic profession in developing and middle-income countries. Chestnut Hill: CIHE Boston College.

Axtmann, R. (2004) The State of the State: the model of the modern state and its contemporary transformations, International Political Science Review, 25(3).

Bauman, Z. (1997) Universities: Old, New, and Different, in: A. Smith \& F. Webster (Eds) The Postmodern University?: contested visions of higher education in society. London: SRHE and Open University Press.

Beck, U. (1999) World Risk Society. Cambridge: Polity Press. 
Beck, U. (2000a) What is Globalization? trans. P. Camiller. Cambridge: Polity Press.

Beck, U. (2000b) The Brave New World of Work, trans. P. Camiller. Cambridge: Polity Press.

Bonoli, G., George, V. \& Taylor-Gooby, P. (2000) European Welfare Futures: towards a theory of retrenchment. Cambridge: Polity Press.

Bottery, M. (2003) The End of Citizenship?: the nation-state, threats to its legitimacy, and citizenship education in the twenty-first century, Cambridge Journal of Education, 33(1), pp. 101-122.

Carnoy, M. (1999) Globalization and Educational Reform: what planners need to know. Paris: UNESCO, International Institute for Educational Planning.

Carnoy, M. \& Rhoten, D. (2002) What Does Globalization Mean for Educational Change?: a comparative approach, Comparative Education Review, 46(1), pp. 1-9.

Dale, R. (1999) Specifying Globalization Effects on National Policy: a focus on the mechanisms, Journal of Education Policy, 14(1).

Deem, R. \& Brehony, K.J. (2005) Management as Ideology: the case of 'new managerialism' in higher education, Oxford Review of Education, 31(2), pp. 213-231.

Delanty, G. (2001) Challenging Knowledge: the university in the knowledge society. Buckingham: SRHE and Open University Press.

Enders, J. \& de Weert, E. (Eds) (2004) The International Attractiveness of the Academic Workplace in Europe. Frankfurt am Main: Gewerkschaft Erziehung und Wissenschaft (GEW).

Esping-Andersen, G. (2001) A Welfare State for the 21st Century, in: A. Giddens (Ed.) The Global Third Way Debate. Cambridge: Polity Press .

European Commission (2003) The Role of Universities in the Europe of Knowledge. COM(2003)58, Brussels.

Fallon, D. (1980) The German University. Boulder: Associated University Press.

Ferge, Z. (2001) European Integration and the Reform of Social Security in the Accession Countries, European Journal of Social Quality, 3(1\&2), pp. 9-25.

Giddens, A. (1994) Beyond Left and Right: the future of radical politics. Stanford: Stanford University Press.

Giddens, A. (1999) Runaway World: how globalisation is reshaping our lives London: Profile Books.

Green, A. (1997) Education, Globalization and the Nation-State. London: Macmillan.

Habermas, J. (2001) The Postnational Constellation: political essays, trans. M. Pensky. Cambridge: MIT Press.

Jessop, B. (1999) The Changing Governance of Welfare: recent trends in its primary functions, scale, and modes of coordination, Social Policy \& Administration, 33(4), 348-359.

Kwiek, M. (2000) The Nation-State, Globalization, and the Modern Institution of the University, Theoria: $A$ Journal of Social and Political Studies, 96 (December).

Kwiek, M. (2001) Globalization and Higher Education, Higher Education in Europe, Xxviii(1).

Kwiek, M. (Ed.) (2003a) The University, Globalization, Central Europe. Frankfurt am Main and New York: Peter Lang.

Kwiek, M. (2003b) Academe in Transition: transformations in the polish academic profession, Higher Education, 45(4).

Kwiek, M. (2003c) The Social Functions of the University in the Context of the Changing State/Market Relations, in J. De Groof \& G. Lauwers (Eds) lobalisation and Competition in Education. Antwerpen: Wolf Legal Publishers.

Kwiek, M. (2004a) Intellectuals, Power, and Knowledge: studies in the philosophy of culture and education. Frankfurt am Main and New York: Peter Lang.

Kwiek, M. (2004b) The Emergent European Educational Policies Under Scrutiny: the Bologna Process from a Central European perspective, European Educational Research Journal, 3(4), pp. 759-776.

Kwiek, M. (2006, forthcoming) The University and the State: a study into global transformations. Frankfurt am Main and New York: Peter Lang.

Lawn, M. (2003) The 'Usefulness' of Learning: the struggle over governance, meaning and the European education space, Discourse, 24(3), pp. 325-336.

Mishra, R. (1999) Globalization and the Welfare State. Cheltenham: Edward Elgar.

Morrow, R.A. \& Torres, C.A. (2000) The State, Globalization, and Educational Policy, in, N.C. Burbules \& C.A. Torres (Eds) Globalization and Education: critical perspectives. London: Routledge.

Neave, G. (Ed.) (2000a) The Universities' Responsibilities to Societies: international perspectives. Amsterdam: Pergamon Press. 
Neave, G. (2000b) Universities' Responsibility to Society: an historical exploration of an enduring issue, in G. Neave (Ed.) The Universities' Responsibilities to Societies: international perspectives. Amsterdam: Pergamon Press.

Neave, G. (2001) The European Dimension in Higher Education: an excursion into the modern use of historical analogues, in: J. Huisman, P. Maassen \& G. Neave (Eds) Higher Education and the Nation-State. Oxford: Pergamon.

Nyborg, P. (2003) Higher Education as a Public Good and a Public Responsibility, Higher Education in Europe, XXVIII(3), pp. 355-359.

Organisation for Economic Cooperation and Development (OECD) (1981) The Welfare State in Crisis. Paris: OECD.

Organisation for Economic Cooperation and Development (OECD) (1998) Redefining Tertiary Education. Paris: OECD.

Pierson, P. (1994) Dismantling the Welfare State?: Reagan, Thatcher, and the politics of retrenchment. Cambridge: Cambridge University Press.

Pierson, P. (2001) Coping with Permanent Austerity, in P. Pierson (Ed.) The New Politics of the Welfare State (Oxford: Oxford University Press).

Readings, B. (1996) The University in Ruins. Boston: Harvard University Press.

Reich, R.B. (1992) The Work of Nations: preparing ourselves for the 21st century. New York: Vintage Books.

Röhrs, H. (1995). The Classical German Concept of the University and Its Influence on Higher Education in the United States. Frankfurt am Main: Peter Lang.

Ruggie, J.G. (1982) International Regimes, Transactions, and Change: embedded liberalism in the postwar economic order, International Organization, 36(2), pp. 379-415.

Ruggie, J.G. (1997) Globalization and the Embedded Liberalism Compromise: the end of an era? Working Paper 97/1, Max Planck Institute for the Studies of Societies.

Scharpf, F. (2000) Negative Integration: states and the loss of boundary control, in C. Pierson \& F.G. Castles (Eds) The Welfare State Reader. Cambridge: Polity Press.

Slaughter, S. \& Leslie, L.L. (1997) Academic Capitalism: politics. policies, and the entrepreneurial university. Baltimore: Johns Hopkins University Press.

Spybey, T. (1996) Globalization and World-Society. Cambridge: Polity Press.

Tanzi, V. (2001) Taxation and the Future of Social Protection, in: A. Giddens (Ed.) The Global Third Way Debate. Cambridge: Polity Press.

Teeple, G. (1995) Globalization and the Decline of Social Reform. Toronto: Garamond Press.

Torres, C.A. (2002) The State, Privatisation and Educational Policy: a critique of neo-liberalism in Latin America and some ethical and political implications, Comparative Education, 38(4).

Welch, A.R. (2001) Globalisation, Post-modernity and the State: comparative education facing the third millennium, Comparative Education, 37(4), pp. 475-492.

Wolf, M. (2001) Will the Nation-State Survive Globalization?, Foreign Affairs, 80(1), pp. 178-190.

World Bank (2002) Constructing Knowledge Societies: new challenges for tertiary education. Washington, DC: World Bank.

MAREK KWIEK is Director of the Center for Public Policy and Professor of Philosophy at Poznan University, Poland. He wrote Intellectuals, Power, and Knowledge: Studies in the Philosophy of Culture and Education (Peter Lang, 2004) and edited The University, Globalization, Central Europe (Peter Lang, 2003). His book The University and the State: a study into global transformations is forthcoming (Peter Lang, 2006). Correspondence: Marek Kwiek, Center for Public Policy, Poznan University, ul. Szamarzewskiego 89, 60-569 Poznan, Poland (kwiekm@amu.edu.pl) 